UDC $339.138+378.4$

http://doi.org/10.21272/mmi.2019.3-15

JEL Classification: 032

Miguel Blanco,

D.Sc., Assistant Lecturer of Economics, University of Cadiz, Spain

Lydia Bares,

Ph.D. candidate of Economic Sciences, Lecturer of Economics, University of Cadiz, Spain

Oksana Hrynevych,

Ph.D. candidate of Economic Sciences, University of Cadiz, Spain

\title{
UNIVERSITY BRAND AS A KEY FACTOR OF GRADUATES EMPLOYMENT
}

Abstract. The aim of this article is to establish a comparison in the degree of efficiency of European universities in the management of the labour insertion of their graduates. The methodology used is the data envelopment analysis (DEA). This type of analysis enables the measurement of the relative efficiency of different organizational units in situations where there is information about multiple inputs and outputs of resources. We define one hundred and twenty-six Decision Making Units (DMU) corresponding to each of the European universities analysed in our study. Developed analysis has allowed to determine the position that each of them occupies in relation to an efficiency frontier. Obtained results have allowed identifying 13 universities that show a score 100. In the interval 9990 are 5. Between 89-80, we have 7. Between 79-70, 7. For the interval 69-60, 13. Between 59-50 are 19. Between 49-40, 20. Between 39-30, 13. And finally between 29-20 there are 19. The universities with a score of 100 belongs to France (Ecole polytechnique and Ecole des Ponts ParisTech), Italy (Politecnico di Torino), Portugal (Universidade Nova de Lisboa), Spain (University of Navarra and University Carlos III of Madrid), Sweden (Chalmers University of Technology), Switzerland (University of St. Gallen) and United Kingdom (University of Cambridge and University of Oxford). These universities represent the optimum of efficiency if they are compared with the others analysed. The universities that have to improve the employability of its graduates by more than $74 \%$ to reach the optimum of efficiency are mostly in the United Kingdom and Sweden, but there are in other regions as Austria, Belgium, Denmark, Germany and Netherlands. Among the main conclusions of this study, we would like to highlight how European university students present employment levels above those workers with lower levels of education. This data points to the high level of general efficiency achieved by university education in improving the degree of employability of its students.

Keywords: data envelopment analysis, efficiency, employment, higher education, productivity.

Introduction. In 2017, the unemployment rate in the European Union was 7.6\%. By gender, 7.4\% corresponded to men and $7.9 \%$ to women. If these data were analysed by educational levels (Figure 1), since 2008 the unemployment rate of citizens with lower levels of education (levels 0-2) was greater than double that of those who have obtained Higher education (levels 5-8).

There are a large number of studies about the relationship between the level of employability of citizens and their educational level. In the last decades, the main research works were Becker (1994), Nickell (1997), Esping-Andersen and Regini (2000), Heath et al. (2008) or Nunez and Livanos (2010). Likewise, the different governments of European countries have incorporated the relationship between training and employment in the formulation of their public policies, developing specific programs to improve the levels of education of their citizens. The European Commission developed several initiatives with the aim of improving professional qualifications.

Specifically, the aim of the strategy for smart, sustainable and inclusive growth - EUROPE 2020 - is to reduce the dropout rate to less than $10 \%$, and at least the $40 \%$ of the younger generation should have completed higher education. The strategy Europe 2020 will implement the following initiatives in different EU countries:

- "Youth on the Move». The objective is to improve the results of education systems and facilitating the entry of young people into the labour market.

Cite as: Blanco, M., Bares, L., Hrynevych, O. (2019). University Brand as a Key Factor of Graduates Employment. Marketing and Management of Innovations, 3, 193-208. http://doi.org/10.21272/mmi.2019.3-15 
- «Agenda for new qualifications and jobs». The purpose is the modernization of labour markets and the empowerment of students through the development of professional skills.

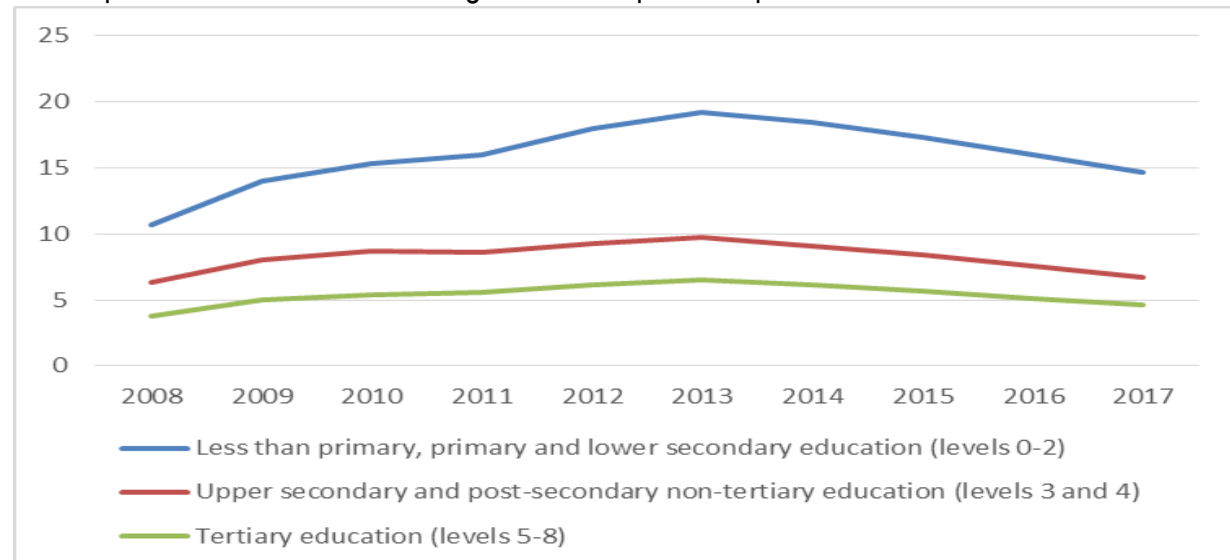

Figure 1. Unemployment rates by educational levels.

Source: Developed by the authors on the basis of Eurostat (2018).

Figure 2 shows the breakdown of public expenditure on education by educational levels. We use the average of the following countries: Belgium, Austria, Czech Republic, Denmark, Finland, France, Germany, Ireland, Italy, Portugal, Spain, Sweden, Switzerland, and United Kingdom. The different regional governments invested more economic resources for tertiary level students than the primary and secondary levels.

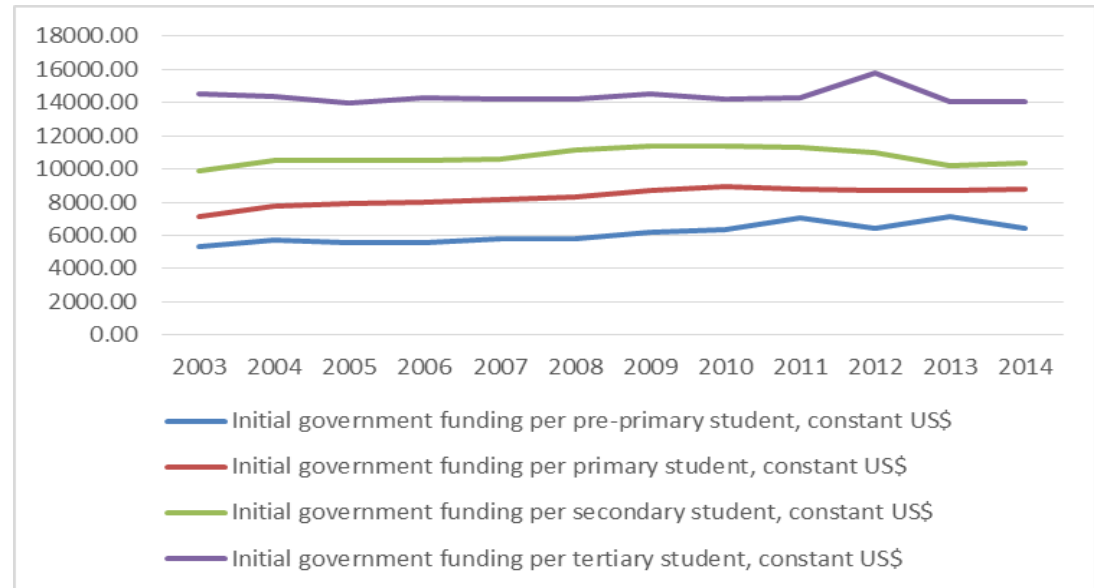

Figure 2. Public expenditure on education by educational levels.

Source: Developed by the authors on the basis of World Bank Data (2018).

Despite the important relationship that exists between educational levels and employment, most of the research carried out in the field of higher education only focus on its function as research centres, obviating the relevant role in improving employability of their graduates. 
There are several international rankings in which the relative position of each university is determined by its research activity:

- Academic Ranking of World Universities (Shanghai Ranking Consultancy);

- World University Rankings (Times Higher Education, Performance Ranking of Scientific Papers for World Universities, Higher Education Evaluation and Accreditation Council of Taiwan);

- Ranking Web of World Universities (Cybermetrics Lab (CCHS), a unit of the Spanish National Research Council (CSIC));

- UTD Top 100 Business School Research Rankings (The UT Dallas' School of Management).

QS World University Rankings (Quacquarelli Symonds) is the only indicator that includes an analysis of the degree of employability of university graduates - QS Graduate Employability Rankings. It is formed from the following variables: reputation of the employer, results of the students, relations between universities and companies, relations between students and employers and the employment rate of graduates.

The main objective of this article is to carry out a study on the degree of efficiency of European universities from a labour perspective. For the purposes of the article was used the Data Envelopment Analysis methodology (DEA), based on a statistical tool that is frequently used by researchers in the performance of comparative efficiency analysis between different decision units (DMU).

Literature review. DEA is a statistical tool frequently used by researchers in their analysis of organizational efficiency and applied to various sectors of social and economic sector. Emrouznejad and Yang (2018) presented a quantitative and qualitative analysis on its application in different studies carried out for the period 1978-2016, and which have been finally published as an article, chapter of a book or conference. A total of 10,300 studies were analysed. Among its main conclusions, it should be noted that since Charnes et al. (1978) published their article entitled «Measuring the efficiency of decision making units», the growth experienced by the research work using this tool has been exponential.

In the analysed areas, the education sector has been studied repeatedly by researchers. It is important to highlight the contributions of Camilli et al. (2010), Bessent and Bessent (1980) or Ruggiero and Vitaliano (1999). In the specific field of higher education, it is worthy to mention the research works of Sarrico et al. (1997), Chu Ng and Li (2000), Avkiran (2001), Taylor and Harris (2004), Warning (2004), Johnes (2006), Lee and Worthington (2006), Leitner et al. (2007), Taylor and Harris (2004) and Koksal and Nalçaci (2006).

Among them, the authors have focused mainly on the field of knowledge management. However, there are not many studies on efficiency analysis from a work perspective. Therefore, this research work is presented to compare the degree of efficiency of European universities from the perspective of labour insertion.

Methodology and research methods. The non-parametric methodology used in this work is the Data Envelopment Analysis (DEA), proposed by Charnes et al. (1978). During the research was defined the production function and 126 Decision Making Units (DMU's) corresponding to the European universities.

The objective of this function is to achieve the greatest increase in the labour insertion indicator, assuming an orientation towards output. In addition, was proposed the utilization the model of variable returns to scale known as BCC-Output, which yields a measure of the pure technical efficiency that ignores the impact of scale size by comparing only one DMU to a unit of similar scale. The main reason is that there is no certainty about the type of return of the production function.

For the choice of inputs/outputs, was carried out a comparative analysis of the main contributions of application of DEA model to the analysis of university efficiency. In this comparison, it has become clear 
how most of the analysed researches have used outputs related to academic activity, research or both at the same time.

Among the authors who use output variables directly related to the teaching activity we find Johnes (2006) and Bessent and Bessent (1980). Specifically, Johnes uses as outputs the total number of first degrees awarded weighted by degree classification; total number of higher degrees awarded (includes both doctorate and other higher degrees); value of the recurrent grant for research awarded by the Higher Education Funding Council for England (HEFCE) in $£$. Bessent and Bessent use the median percentile reading achievement for only those pupils in attendance at the school for a full year; median percentile mathematics achievement test score for only those pupils in attendance for a full year.

Chu $\mathrm{Ng}$ and $\mathrm{Li}$ (2000) and Warning (2004) apply outputs linked to the research activity. Chu $\mathrm{Ng}$ and $\mathrm{Li}$ use the number of manuscripts; number of articles; number of recognized research outputs; number of contracts and number of prizes. Warning analyse outputs related to Science Citation Index (SCI) data for the natural sciences and on the Social Science Citation Index (SSCI) and the Arts and Humanities Index (AHI) for the social sciences. Since the ISI3 incorporates only quality journals in its indexes, the computed score provides information on both quality and quantity of publications. The "publication" variable includes total number of publications from 1997 to 1999 , amounting to 14,176 in the SCl and 893 in the SSCl and $\mathrm{AHI}$.

Finally, it is important to highlight how most of the researches consulted use outputs related to both teaching and research activity. Taylor and Harris (2004), Martín (2007), Correas and Jorge (2010), Lee and Worthington (2016), Sagarra et al. (2017), Marti et. al. (2014), Avkiran (2001), Leitner et al. (2007), Taylor and Harris (2004) y Koksal and Nalçaci (2006). Taylor and Harris employ the completed academic qualifications (degrees, diplomas and certificates); research output (books, articles in approved journals, conference proceedings and patents/licenses and research income). Martín the number of students; number of graduates; average score in the evaluation survey; teachers' load; number of publications; external aid for research; number of Ph.D. thesis; number of citations. Correas and Jorge the number of students enrolled; number of graduate students; number of Ph.D. thesis; number of publications; number of scientific documents in indexed journals; $\%$ of teaching staff with one or more research sections; number of research projects; patents applications. Lee and Worthington make use of an indicator of publications and the Grants' Students. Sagarra et al. the papers indexed in Scopus and the graduates. Marti et. al. the number of graduates; the revenue from research and the number of Ph.D. thesis. Avkiran the overseas fee-paying enrolments, EFTSU non-overseas fee-paying postgraduate enrolments, EFTSU. Leitner et al. use the examinations; the finished supervised diploma thesis; monographs; journal papers; project reports; presentations; other publications; finished supervised PhD thesis; patents; financial funds provided by third parties; finished projects and personal; finished projects of the department. Taylor and Harris the degrees; diplomas and certificates; books; articles in approved journals; conferences; Patents/licenses; research income. Koksal and Nalçaci use the research activities and quality; education activities and quality; other activities and Graduates.

It shows how researchers have oriented their research to the analysis of the degree of efficiency in its academic aspect, avoiding the important role that universities are functioning as centres of professional insertion of their graduates. Therefore, in this article, was proposed to use a variable output related to the improvement in the degree of employability of students. In particular, the variable is the overall score calculated for the indicator QS Graduate Employability and which is the result of weighting the following variables: reputation of the employer; student marks; university-industry collaboration, Employer/Student Connections and Graduate Employment Rate. Table 1 shows the weighting factor applied to the variables, as well as their definition. 
Table 1. Methodology for calculating the indicator QS Graduate Employability

\begin{tabular}{|c|c|c|c|}
\hline Variable & $\begin{array}{c}\text { Weighting } \\
\text { factor }\end{array}$ & Definition \\
\hline $\begin{array}{c}\text { University } \\
\text { reputation }\end{array}$ & $30 \%$ & $\begin{array}{c}\text { Value that entrepreneurs assign to the universities that offer the } \\
\text { most competent, innovative and effective graduates. }\end{array}$ \\
\hline Graduate students & $25 \%$ & $\begin{array}{c}\text { Number of students who are considered as innovative, creative, } \\
\text { wealthy, enterprising and / or philanthropic people of the world. }\end{array}$ \\
\hline $\begin{array}{c}\text { Industry-university } \\
\text { collaboration }\end{array}$ & $25 \%$ & $\begin{array}{c}\text { This indicator comprises from two parts. First, it uses Elsevier's } \\
\text { Scopus database to identify which universities are collaborating } \\
\text { successfully with international companies. Second, it considers the } \\
\text { associations related to job placement that are informed by the } \\
\text { institutions and validated by the QS research team. }\end{array}$ \\
\hline $\begin{array}{c}\text { Participation of } \\
\text { employers in } \\
\text { university activities } \\
\text { for employment }\end{array}$ & $10 \%$ & $\begin{array}{c}\text { This indicator implies adding the number of entrepreneurs who } \\
\text { have actively participated in the university campus in last twelve } \\
\text { months, allowing students the opportunity to establish contacts } \\
\text { and acquire information on how to work in their companies. This } \\
\text { 'active presence' can take the form of participating in career fairs, } \\
\text { organizing company presentations or any other self-promotion } \\
\text { activity. }\end{array}$ \\
\hline $\begin{array}{c}\text { University } \\
\text { employment rate }\end{array}$ & $10 \%$ & $\begin{array}{c}\text { Measures the proportion of graduates (excluding those who chose } \\
\text { to continue studying or are not available to work) in a full-time or } \\
\text { part-time job within 12 months after graduation. }\end{array}$ \\
\hline
\end{tabular}

Source: Developed by the authors on the basis of QS Graduate Employment (2018).

The choice of output has conditioned the number of universities used in the study, since there is no calculation for all European universities. The following table shows the selected universities and country of origin.

Table 2. Universities analysed in the study

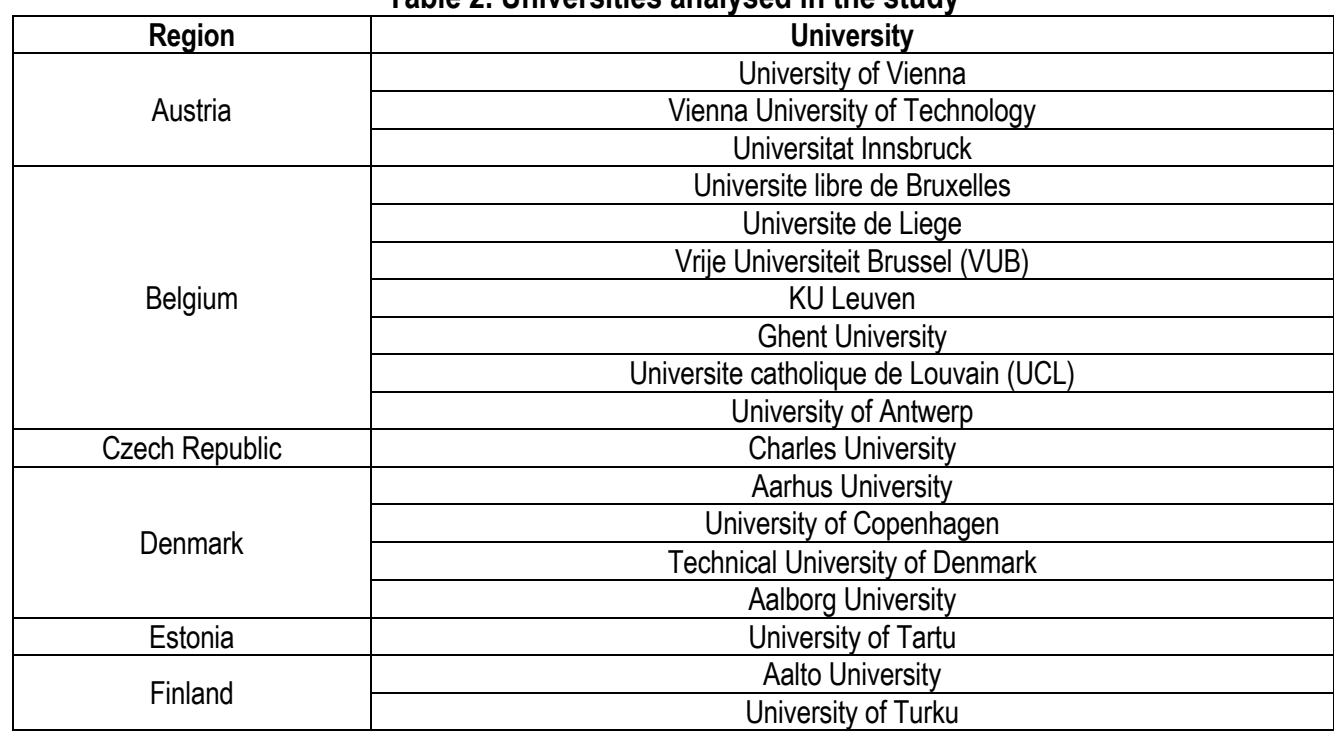


Continued Table 2

\begin{tabular}{|c|c|}
\hline \multirow{9}{*}{ France } & Ecole Polytechnique \\
\hline & CentraleSupelec \\
\hline & Sciences Po \\
\hline & Universite Pierre et Marie Curie (UPMC) \\
\hline & Universite Paris 1 Pantheon-Sorbonne \\
\hline & Universite Paris-Dauphine, PSL Research University \\
\hline & Ecole des Ponts ParisTech \\
\hline & Universite de Montpellier \\
\hline & Ecole normale superieure, Paris \\
\hline \multirow{18}{*}{ Germany } & KIT, Karlsruhe Institute of Technology \\
\hline & Technische Universitat Darmstadt \\
\hline & Technical University of Munich \\
\hline & Technische Universitat Berlin (TU Berlin) \\
\hline & RWTH Aachen University \\
\hline & Ludwig-Maximilians-Universitat Munchen \\
\hline & Universitat Stuttgart \\
\hline & Friedrich-Alexander-Universitat Erlangen-Nurnberg \\
\hline & Universitat Konstanz \\
\hline & Technische Universitat Dresden \\
\hline & Humboldt-Universitat zu Berlin \\
\hline & Universitat Mannheim \\
\hline & Eberhard Karls Universitat Tubingen \\
\hline & Freie Universitaet Berlin \\
\hline & Universitat Frankfurt am Main \\
\hline & University of Gottingen \\
\hline & Johannes Gutenberg Universitat Mainz \\
\hline & Rheinische Friedrich-Wilhelms-Universitat Bonn \\
\hline \multirow{4}{*}{ Ireland } & University College Dublin \\
\hline & Trinity College Dublin, The University of Dublin \\
\hline & Dublin City University \\
\hline & National University of Ireland Galway \\
\hline \multirow{5}{*}{ Italy } & Politecnico di Milano \\
\hline & Alma Mater Studiorum - University of Bologna \\
\hline & Sapienza University of Rome \\
\hline & Politecnico di Torino \\
\hline & Università di Padova \\
\hline \multirow{9}{*}{ Netherlands } & Maastricht University \\
\hline & University of Twente \\
\hline & Delft University of Technology \\
\hline & University of Amsterdam \\
\hline & Erasmus University Rotterdam \\
\hline & Eindhoven University of Technology \\
\hline & Leiden University \\
\hline & University of Groningen \\
\hline & Vrije Universiteit Amsterdam \\
\hline \multirow{3}{*}{ Portugal } & University of Lisbon \\
\hline & Universidade Nova de Lisboa \\
\hline & University of Porto \\
\hline
\end{tabular}


Continued Table 2

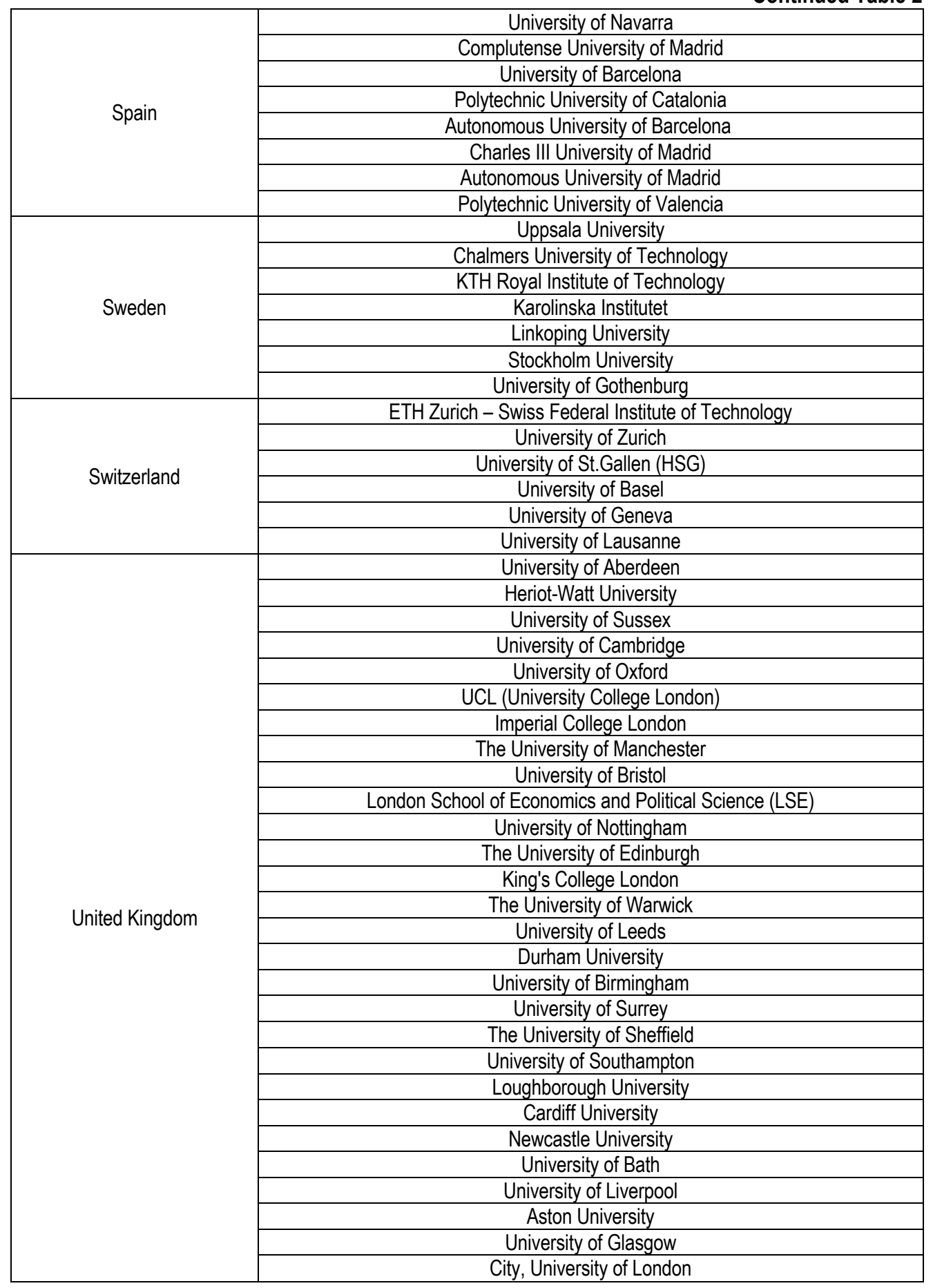


Continued Table 2

\begin{tabular}{|l|c|}
\hline \multirow{4}{*}{ United Kingdom } & Queen's University Belfast \\
\cline { 2 - 3 } & The University of Exeter \\
\cline { 2 - 3 } & Lancaster University \\
\cline { 2 - 3 } & University of St Andrews \\
\cline { 2 - 3 } & University of York \\
\cline { 2 - 3 } & University of Reading \\
\cline { 2 - 3 } & Oxford Brookes University \\
\cline { 2 - 3 } & Queen Mary University of London \\
\cline { 2 - 3 } & University of Essex \\
\cline { 2 - 3 } & University of Kent \\
\cline { 2 - 3 } & University of Leicester \\
\cline { 2 - 3 } & University of Strathclyde \\
\hline
\end{tabular}

Source: developed by the authors on the basis of QS Graduate Employment (2018).

Regarding the input variables used in this article a detailed analysis of the input variables used by the researchers has been carried out prior to their definition. In general, the authors use as input variables related to the teaching staff and the students. Therefore, Johnes (2006) uses the total number of FTE undergraduate students studying for a first degree multiplied by the average A level points for first year full-time undergraduate students (A level score is averaged over 1994/95, 1995/96, 1996/97 and 1997/98. Note that $A=10, B=8, C=6, D=4, E=2)$; total number of FTE postgraduate students; total number of full-time academic staff for teaching, or teaching and research, or research only purposes; total depreciation and interest payable in $£$; total expenditure on central libraries and information services, and on central computer and computer networks excluding academic staff costs and depreciation in $£$ and the expenditure on central administration and central services excluding academic staff costs and depreciation in $£$. Bessent and Bessent (1980) consider the pupil inputs measured by the California Achievement Test in May, 1976. Chu Ng and Li (2000) the number of researchers, number of research supporting staff and the budget funds (in thousand RMB). Avkiran (2001) take into account the academic staff and non-academic staff. Taylor and Harris (2004) uses the total expenditure, capital employed, capital employed and student numbers, capital employed and staff numbers, capital employed and adjusted expenditure, capital employed and total expenditure and student numbers and staff numbers. Warning (2004) consider the inputs used to measure staff, both scientific and nonscientific, and overhead expenditures, including spending on library resources, computing services and further infrastructure. Martín (2007) uses the number of full-time lecturers; number of part-time lecturers; number of full-time equivalent lecturers; number of permanent lecturers; number of non-permanent lecturers; number of scholars; lecturers' salary; number of students; teacher load; infrastructures; number of computers; physical investment; budget; external aid for research and expenses in books and magazines. Correas and Jorge (2010) used the personal expenses; current expenses in goods and services; lecturers' expenses and other expenses. Marti et. al. (2014) the number of students enrolled; current expenses; number of full-time lecturers. Lee and Worthington (2016) employ the FTE academic and PhD students. Finally, Sagarra et al. (2017) use the full time equivalent faculty, total enrolment and the first joining graduates.

As a result, were chosen two types of input variables. On the one hand, the one related to the undergraduate and postgraduate students. On the other, the teaching staff, both national and foreign.

Table 3 shows the production function in the level of university work efficiency on which the Data Envelopment Analysis has been applied, in which the inputs and outputs are disaggregated. 
Table 3. Production function

\begin{tabular}{|c|c|c|c|}
\hline Type & \multicolumn{2}{|c|}{ Variable } & Description \\
\hline Output & \multicolumn{2}{|c|}{ (QS) Overall score } & $\begin{array}{c}\text { Overall score calculated for the indicator } \\
\text { QS Graduate Employability }\end{array}$ \\
\hline \multirow{6}{*}{ Inputs } & \multirow{2}{*}{$\begin{array}{l}\text { (I.1) Bachelor } \\
\text { students }\end{array}$} & $\begin{array}{c}\text { (I.1.1) National } \\
\text { bachelor students }\end{array}$ & \multirow{2}{*}{$\begin{array}{l}\text { Number of national and international } \\
\text { students enrolled in bachelor studies }\end{array}$} \\
\hline & & $\begin{array}{l}\text { (I.1.2) International } \\
\text { bachelor students }\end{array}$ & \\
\hline & \multirow{2}{*}{$\begin{array}{l}(1.2) \\
\text { Postgraduate } \\
\text { students }\end{array}$} & $\begin{array}{l}\text { (1.2.1) National } \\
\text { postgraduate } \\
\text { students }\end{array}$ & \multirow{2}{*}{$\begin{array}{l}\text { Number of national and international } \\
\text { students enrolled in postgraduate studies }\end{array}$} \\
\hline & & $\begin{array}{l}\text { (I.2.2) International } \\
\text { postgraduate } \\
\text { students }\end{array}$ & \\
\hline & \multirow{2}{*}{$\begin{array}{l}\text { (I.3) Teaching } \\
\text { staff }\end{array}$} & $\begin{array}{l}\text { (I.3.1) National } \\
\text { teaching staff }\end{array}$ & \multirow{2}{*}{$\begin{array}{l}\text { National and international teaching staff } \\
\text { related to bachelor and postgraduate } \\
\text { studies }\end{array}$} \\
\hline & & $\begin{array}{l}\text { (I.3.2) International } \\
\text { teaching staff }\end{array}$ & \\
\hline
\end{tabular}

Sources: developed by the authors.

The level of reliability of the model depends on the relationship between the number of variables inputs and outputs - defined in the production function and the DMU's considered. If there is not a suitable relationship between them, could be obtained results in which all the DMU's are efficient. This would complicate the results and a scenario of unrealistic maximum efficiency would become the decision-making condition.

To avoid this situation, was used the Cooper's Rule, which establishes the relationship between DMU's, inputs and outputs. In particular, the rule indicates that:

$$
\text { DMU's } \geq a \text { (input + outputs) }
$$

The above means that the number of DMU's considered in the model must be greater or at least equal to a times the sum of the inputs and outputs. The rule establishes that the minimum value to assume is $a=1.5$, although many authors, with the purpose of obtaining more robust results, usually assume values of 2 or 3, as Pastor (1995), Belmonte and Plaza (2008) or Bartual and Garrido (2011). For the analysis developed in this investigation, we consider $a>3$, above the minimum indicated by the Cooper's Rule.

Results. The model used is this article assumes the existence of variable returns to scale - BBC in the estimation of the degree of efficiency. Likewise, was contemplated an orientation towards output (BBC-output model), based on the hypothesis of maximizing the QS indicator without having prior knowledge of the returns to scale that may be generated against the quantity of inputs applied to said maximizing purpose. Table 4 summarizes the statistics of the inputs/outputs variables defined in the production function.

Table 5 shows the results obtained from the application of the model. In the column (SCORE) were collected the relative position of each university with respect to an optimal point that has been assigned the value 100. This allowed to establish an order related to each DMU. Likewise, we add a column (IHE increase) that indicates the percentage of increase that the analysed DMUs should do in order to have their score at the maximum efficiency level. 
Table 4. Summary of variable statistics inputs / outputs for the production function

\begin{tabular}{|c|c|c|c|c|c|c|c|}
\hline \multirow{2}{*}{ Indicator } & \multirow{2}{*}{$\begin{array}{c}\text { QS GRADUATE } \\
\text { EMPLOYABILITY } \\
\text { RANKINGS } \\
\text { OVERAL SCORE } \\
\text { AVERAGE }\end{array}$} & \multicolumn{2}{|c|}{ National students } & \multicolumn{2}{|c|}{ International students } & \multicolumn{2}{|c|}{ Teaching staff } \\
\hline & & PG Students & UG Students & PG Students & UG Students & National & \begin{tabular}{|l|} 
International \\
\end{tabular} \\
\hline Variance & 336.2033392 & $50,189,620.52$ & $83,015,348.52$ & $2,591,532.249$ & $2,206,117.449$ & $1,047,229.18$ & $301,477.2725$ \\
\hline $\begin{array}{l}\text { Standard } \\
\text { deviation }\end{array}$ & 18.40789531 & $7,112.300218$ & $9,147.076729$ & $1,616.149131$ & $1,491.136631$ & $1,027.363172$ & 551.2269127 \\
\hline $\begin{array}{c}\text { Quasi- } \\
\text { Variance }\end{array}$ & 338.8506096 & $50,584,8$ & 83,66 & 2611 & $23,488.452$ & $\mid 1,055,475.087$ & $303,851.1093$ \\
\hline Median & 40.05 & $6,762.76$ & $12,890.675$ & $1,984.605$ & $2,201.22$ & 1,265 & 451 \\
\hline $\begin{array}{l}\text { Coefficien } \\
\text { of curtosis }\end{array}$ & -0.075367957 & 13.33573801 & 6.594644738 & 1.56521559 & 0.986359277 & 1.101068476 & 5.294569167 \\
\hline $\begin{array}{l}\text { Coefficien } \\
\text { of } \\
\text { asymmetr }\end{array}$ & 0.674883849 & 2.885657687 & 1.903254019 & 1.120916241 & 1.022121924 & 1.126259502 & 2.159860583 \\
\hline Maximum & 96 & $54,114.5$ & $60,302.82$ & $8,102.08$ & $8,169.7$ & 5,147 & 2,964 \\
\hline Minimum & 20.8 & $1,503.2$ & 133.49 & 7.48 & 0 & 103 & 9 \\
\hline Rank & 75.2 & $52,611.3$ & $60,169.33$ & $8,094.6$ & $8,169.7$ & 5,044 & 2,955 \\
\hline
\end{tabular}

Source: Developed by the authors.

Table 5. Efficiency model «BBC-Output»

\begin{tabular}{|c|c|c|}
\hline University & Score & Target \\
\hline Ecole normale superieure. Paris & 100 & 0 \\
\hline Ecole des Ponts ParisTech & 100 & 0 \\
\hline University of St.Gallen (HSG) & 100 & 0 \\
\hline Universidade Nova de Lisboa & 100 & 0 \\
\hline Chalmers University of Technology & 100 & 0 \\
\hline Charles III University of Madrid & 100 & 0 \\
\hline Politecnico di Torino & 100 & 0 \\
\hline Centrale Supelec & 100 & 0 \\
\hline University of Navarra & 100 & 0 \\
\hline Ecole Polytechnique & 100 & 0 \\
\hline University of Oxford & 100 & 0 \\
\hline ETH Zurich - Swiss Federal Insti & 100 & 0 \\
\hline University of Cambridge & 100 & 0 \\
\hline Aston University & 96.43 & 3.57 \\
\hline KIT. Karlsruhe Institute of Tech & 96.28 & 3.72 \\
\hline Politecnico di Milano & 92.97 & 7.03 \\
\hline UCL (University College London) & 91.98 & 8.02 \\
\hline Complutense University of Madrid & 90.12 & 9.88 \\
\hline Technische Universitat Darmstadt & 89.46 & 10.54 \\
\hline Delft University of Technology & 87.71 & 12.29 \\
\hline Imperial College London & 86.37 & 13.63 \\
\hline London School of Economics and Political Science (LSE) & 84.8 & 15.2 \\
\hline
\end{tabular}


Continued Table 5

\begin{tabular}{|c|c|c|}
\hline The University of Manchester & 83.75 & 16.25 \\
\hline University of Barcelona & 81.77 & 18.23 \\
\hline University of Bristol & 81.26 & 18.74 \\
\hline University of Nottingham & 77.28 & 22.72 \\
\hline The University of Warwick & 76.59 & 23.41 \\
\hline KTH Royal Institute of Technology & 76.55 & 23.45 \\
\hline Durham University & 76.07 & 23.93 \\
\hline Technische Universitat Berlin (TU Berlin) & 75.92 & 24.08 \\
\hline University College Dublin & 75.65 & 24.35 \\
\hline Universitat Mannheim & 75.6 & 24.4 \\
\hline University of Leeds & 75.32 & 24.68 \\
\hline Università di Padova & 75.26 & 24.74 \\
\hline Alma Mater Studiorum - University of Bologna & 74.38 & 25.62 \\
\hline The University of Edinburgh & 73.63 & 26.37 \\
\hline Polytechnic University of Catalonia & 73.48 & 26.52 \\
\hline Sapienza University of Rome & 73.3 & 26.7 \\
\hline King's College London & 73.23 & 26.77 \\
\hline Technical University of Munich & 73.21 & 26.79 \\
\hline RWTH Aachen University & 71.32 & 28.68 \\
\hline KU Leuven & 71.18 & 28.82 \\
\hline Ludwig-Maximilians-Universitat Munchen & 69.41 & 30.59 \\
\hline University of Turku & 69.08 & 30.92 \\
\hline University of Lisbon & 68.81 & 31.19 \\
\hline University of Birmingham & 67.93 & 32.07 \\
\hline University of Amsterdam & 65.77 & 34.23 \\
\hline Trinity College Dublin. The University of Dublin & 64.44 & 35.56 \\
\hline Eindhoven University of Technology & 64.25 & 35.75 \\
\hline Aarhus University & 63.96 & 36.04 \\
\hline University of Zurich & 63.82 & 36.18 \\
\hline University of Surrey & 62.95 & 37.05 \\
\hline University of Porto & 61.79 & 38.21 \\
\hline Erasmus University Rotterdam & 60.51 & 39.49 \\
\hline Autonomous University of Barcelona & 60.4 & 39.6 \\
\hline Loughborough University & 58.46 & 41.54 \\
\hline The University of Sheffield & 57.77 & 42.23 \\
\hline University of Southampton & 57.35 & 42.65 \\
\hline Universitat Stuttgart & 56.78 & 43.22 \\
\hline University of Copenhagen & 56.65 & 43.35 \\
\hline University of St Andrews & 56.16 & 43.84 \\
\hline Friedrich-Alexander-Universitat erlangen-nuremberg & 55.74 & 44.26 \\
\hline University of Bath & 54.52 & 45.48 \\
\hline Universitat Konstanz & 54.42 & 45.58 \\
\hline Ghent University & 54.3 & 45.7 \\
\hline Universite Paris-Dauphine. PSL Researchd University & 54.28 & 45.72 \\
\hline
\end{tabular}


Continued Table 5

\begin{tabular}{|c|c|c|}
\hline Sciences Po & 53.2 & 46.8 \\
\hline Autonomous University of Madrid & 53.16 & 46.84 \\
\hline Cardiff University & 53.13 & 46.87 \\
\hline Charles University & 52.86 & 47.14 \\
\hline Newcastle University & 52.47 & 47.53 \\
\hline Universite Pierre et Marie Curie (UPMC) & 52.04 & 47.96 \\
\hline Universite catholique de Louvain & 51.06 & 48.94 \\
\hline Maastricht University & 50.58 & 49.42 \\
\hline University of Tartu & 49.93 & 50.07 \\
\hline Polytechnic University of Valencia & 49.64 & 50.36 \\
\hline Vienna University of Technology & 49.6 & 50.4 \\
\hline University of Liverpool & 49.54 & 50.46 \\
\hline Universite libre de Bruxelles & 48.49 & 51.51 \\
\hline City. University of London & 48.14 & 51.86 \\
\hline Universite Paris 1 Pantheon-Sorbonne & 47.97 & 52.03 \\
\hline Queen's University Belfast & 47 & 53 \\
\hline Technische Universitat Dresden & 46.99 & 53.01 \\
\hline University of Glasgow & 46.9 & 53.1 \\
\hline Aalto University & 44.86 & 55.14 \\
\hline University of Vienna & 43.62 & 56.38 \\
\hline Humboldt-Universitat zu Berlin & 43.34 & 56.66 \\
\hline Lancaster University & 43.22 & 56.78 \\
\hline Leiden University & 42.61 & 57.39 \\
\hline Uppsala University & 42.59 & 57.41 \\
\hline The University of Exeter & 42.54 & 57.46 \\
\hline University of York & 42.38 & 57.62 \\
\hline Universite de Montpellier & 40.91 & 59.09 \\
\hline University of Groningen & 40.42 & 59.58 \\
\hline University of Basel & 38.88 & 61.12 \\
\hline Karolinska Institutet & 37.55 & 62.45 \\
\hline Universitat Frankfurt am Main & 37.55 & 62.45 \\
\hline Freie Universitaet Berlin & 37.48 & 62.52 \\
\hline Vrije Universiteit Amsterdam & 37.39 & 62.61 \\
\hline Technical University of Denmark & 37.26 & 62.74 \\
\hline Universite de Liege & 37.12 & 62.88 \\
\hline University of Reading & 37.05 & 62.95 \\
\hline University of Aberdeen & 36.74 & 63.26 \\
\hline Dublin City University & 35.81 & 64.19 \\
\hline Eberhard Karls Universitat Tubin & 35.73 & 64.27 \\
\hline University of Geneva & 35.52 & 64.48 \\
\hline University of Lausanne & 35.46 & 64.54 \\
\hline Oxford Brookes University & 26.97 & 73.03 \\
\hline National University of Ireland Galway & 26.49 & 73.51 \\
\hline University of Twente & 25.96 & 74.04 \\
\hline
\end{tabular}


Continued Table 5

\begin{tabular}{|c|c|c|}
\hline Rheinische Friedrich-Wilhelms-Universitat Bonn & 25.96 & 74.04 \\
\hline Heriot-Watt University & 25.94 & 74.06 \\
\hline Linkoping University & 25.78 & 74.22 \\
\hline University of Essex & 25.68 & 74.32 \\
\hline University of Gothenburg & 25.61 & 74.39 \\
\hline University of Leicester & 25.57 & 74.43 \\
\hline University of Sussex & 25.57 & 74.43 \\
\hline Aalborg University & 25.55 & 74.45 \\
\hline University of Strathclyde & 25.53 & 74.47 \\
\hline Johannes Gutenberg Universitat Mainz & 25.47 & 74.53 \\
\hline University of Kent & 25.22 & 74.78 \\
\hline University of Antwerp & 25.13 & 74.87 \\
\hline Stockholm University & 25.11 & 74.89 \\
\hline University of Gottingen & 25.1 & 74.9 \\
\hline Universitat Innsbruck & 25.07 & 74.93 \\
\hline Queen Mary University of London & 24.75 & 75.25 \\
\hline
\end{tabular}

Source: Developed by the authors.

Conclusions. In this article, was carried out a comparative analysis of the degree of efficiency of European universities in terms of labour insertion of their graduates. Firstly, was analyzed the literature, and was found that the majority of studies about university performance assess their research activity, leaving in the background its' role in the improvement of the degree of employability of universities' graduates.

For the purposes of the article was used the methodology to determine the degree of university work efficiency which incorporates an eminently business concept to university management, such as the efficiency frontier, in which a production function composed of three inputs has been defined undergraduate, graduate and postgraduate students, teaching staff (national and international) - and one output - (QS) Overall score. The DEA analysis applied to this function determine the relative position of each university with respect to the efficiency frontier. The assessment has been made of each DMU that are determined by the spatial position of each one of the universities with respect to frontier to which we give the most efficient value.

Since the way in which the conversion of inputs into outputs is not directly determined exists a certain element of subjectivity in the analysis. Thus, the choice of other input or output variables in the application of the DEA would probably yield different values. To minimize the subjective component, was done a thorough analysis of the main inputs/outputs used in other investigations.

The results of this research show remarkable differences between the analyzed DMU. Thus, it has been possible to determine the existence of nine groups. Thus, 13 universities show a score of 100 . In the interval 99-90 there are 5. Between 89-80, we have 7. Between 79-70, 7. For the interval 69-60, 13. Between 59-50 there are 19 between 49-40, 20. Between 39-30, 13. And finally between 29-20 there are 19.

The universities with a score of 100 belongs to France (Ecole polytechnique and Ecole des Ponts ParisTech), Italy (Politecnico di Torino), Portugal (Universidade Nova de Lisboa), Spain (University of Navarra and University Carlos III of Madrid), Sweden (Chalmers University of Technology), Switzerland (University of St. Gallen) and United Kingdom (University of Cambridge and University of Oxford). These universities represent the optimum of efficiency if they are compared with the others analyzed. 
Likewise, has been included an analysis of objectives in which is indicated the effort that the DMUs must make in groups. Thus, those of the second group have to increase the score by $6 \%$. The third group $15 \%$. The fourth $25 \%$. The fifth $34 \%$. The sixth one $45 \%$. The seventh $54 \%$, the eighth $63 \%$ and finally the ninth $74 \%$. The universities that have to improve the employability of its graduates by more than $74 \%$ to reach the optimum of efficiency are mostly in the United Kingdom and Sweden, but there are in other regions as Austria, Belgium, Denmark, Germany and Netherlands. This increase in the levels of effort was made more necessary by the greater potential that the university students have to find work on those people who have a lower level education.

Also, was considered necessary to broaden this analysis by means of a comparative study of the specific labour insertion policies developed by the analyzed DMUs, in such way that from it can be created a bank of good practices where can be reflected university policies of employment that are getting better results. Have to be mentioned that this field of research due to the economic importance of its results, should be considered more abundantly by the authors.

Author Contributions. Conceptualization - M. B. and L. B. Data curation - M. B. and L. B. Formal analysis - M. B. and L. B. Funding acquisition - M.B. and L.B. Investigation - M. B. and L. B. Methodology - M. B. and L. B. Project administration - M. B. and L. B. Resources - M. B. and L. B. Software - M. B. and L. B. Supervision - M. B. and L. B. Validation - M. B. and L. B. Visualization M. B. and L. B. and O. H. Writing - original draft - M. B. and L. B. and O. H. Writing - review \& editing M. B. and L. B. and O. H.

Funding: «This research received no external funding».

\section{References}

Avkiran, N. K. (2001). Investigating technical and scale efficiencies of Australian universities through data envelopment analysis. Socio-Economic Planning Sciences, 35(1), 57-80.

Bartual, A. M. and Garrido, R. S. (2011). Analisis de la eficiencia y liderazgo de los puertos espanoles por areas geograficas. Revista de estudios regionales, (91), 161-184.

Becker, G. S. (1994). Human capital revisited. In Human Capital: A Theoretical and Empirical Analysis with Special Reference to Education (3rd Edition) (pp. 15-28). The university of Chicago press.

Belmonte, L.J. and Plaza, J.A. (2008). Analisis de la eficiencia en las cooperativas de credito en Espana. Una propuesta metodológica basada en el analisis envolvente de datos (DEA). Revista CIRIEC, 63, 113-133.

Bessent, A. M. and Bessent, E. W. (1980). Determining the comparative efficiency of schools through data envelopment analysis. Educational Administration Quarterly, 16(2), 57-75.

Camilli, G., Vargas, S., Ryan, S. and Barnett, W. S. (2010). Meta-analysis of the effects of early education interventions on cognitive and social development. Teachers College Record, 112(3), 579-620.

Charnes, A., Cooper, W. W. and Rhodes, E. (1978). Measuring the efficiency of decision making units. European journal of operational research, 2(6), 429-444.

Correas, A. G. and Jorge, M. L. (2010). Analisis de diferentes medidas de la eficiencia investigadora y factores explicativos en las universidades públicas espanolas. Investigaciones de Economía de la Educación, 5, 703-732.

Chu Ng, Y. and Li, S. K. (2000). Measuring the research performance of Chinese higher education institutions: an application of data envelopment analysis. Education Economics, 8(2), 139-156. 
Emrouznejad, A. and Yang, G. L. (2018). A survey and analysis of the first 40 years of scholarly literature in DEA: 1978-2016. Socio-Economic Planning Sciences, 61, 4-8.

Esping-Andersen, G., \& Regini, M. (Eds.). (2000). Why deregulate labour markets?. OUP Oxford.

Heath, A. F., Rothon, C. and Kilpi, E. (2008). The second generation in Western Europe: Education, unemployment, and occupational attainment. Annu. Rev. Sociol, 34, 211-235.

Johnes, J. (2006). Data envelopment analysis and its application to the measurement of efficiency in higher education. Economics of Education Review, 25(3), 273-288.

Koksal, G. and Nalçaci, B. (2006). The relative efficiency of departments at a Turkish engineering college: A data envelopment analysis. Higher Education, 51(2), 173-189.

Lee, B. L. and Worthington, A. C. (2016). A network DEA quantity and quality-orientated production model: An application to Australian university research services. Omega, 60, 26-33.

Leitner, K. H., Prikoszovits, J., Schaffhauser-Linzatti, M., Stowasser, R. and Wagner, K. (2007). The impact of size and specialisation on universities' department performance: A DEA analysis applied to Austrian universities. Higher Education, 53(4), 517-538.

Marti, M. L., Puertas, R., \& Calafat, C. (2014). Calidad y eficiencia de las Universidades Públicas Espanolas. Revista de estudios regionales, 99, 135-154.

Martín R. (2007). La eficiencia productiva en el ambito universitario: aspectos claves para su evaluación. Estudios de Economía aplicada, 25(3), 791-811.

Nickell, S. (1997). Unemployment and labor market rigidities: Europe versus North America. Journal of Economic perspectives, 11(3), 55-74.

Nunez, I. and Livanos, I. (2010). Higher education and unemployment in Europe: an analysis of the academic subject and national effects. Higher Education, 59(4), 475-487.

Pastor, J. M. (1995). Eficiencia, cambio productivo y cambio tecnico en los bancos y cajas de ahorro espanolas: Un analisis de frontera no parametrico. Valencia, Institut Valencià d'Investigacions Economiques.

Ruggiero, J. and Vitaliano, D. F. (1999). Assessing the efficiency of public schools using data envelopment analysis and frontier regression. Contemporary Economic Policy, 17(3), 321-331.

Sagarra, M., Mar-Molinero, C. and Agasisti, T. (2017). Exploring the efficiency of Mexican universities: Integrating data envelopment analysis and multidimensional scaling. Omega, 67, 123-133.

Sarrico, C. S., Hogan, S. M., Dyson, R. G. and Athanassopoulos, A. D. (1997). Data envelopment analysis and university selection. Journal of the operational research society, 48(12), 1163-1177.

Taylor, B. and Harris, G. (2004). Relative efficiency among South African universities: A data envelopment analysis. Higher Education, 47(1), 73-89.

Warning, S. (2004). Performance differences in German higher education: Empirical analysis of strategic groups. Review of Industrial Organization, 24(4), 393-408.

Мігуел Бланко, D.Sc., Кадізький університет (Іспанія);

Лідія Барес, Кадізький університет (Іспанія);

Оксана Гриневич, Кадізький університет (Іспанія).

Бренд універсиету як ключовий фактор працевлаштування випускників

Метою даної статmі є порівняння європейських університетів за ступенем успішності працевлаштування їх випускників. Дослідження здійснено з використанням методу - аналіз середовища фрункціонування (АСФ). Авторами зазначено, що даний підхід дозволив визначити відносну ефективність різних організаційних підрозділів на основі аналізу інформації про багатоканальні входи та виходи всіх видів ресурсів. Емпіричне дослідження проведено на основі панельних даних, сформованих для вибірки з 1026 підрозділів відповідальних за прийняття рішень (ППР) у європейських університетах. Проведений аналіз дозволив проаранжувати досліджувані університети в залежності від успішності працевлаштування їх випускників. На основі отриманих 
емпіричних результатів дослідження виокремлено 13 університетів, які за шкалою мають 100 балів. До даної категорії увійшли університети з таких країн як: Франція (École polytechnique and École des Ponts ParisTech), Iталія (Politecnico di Torino), Португалія (Universidade Nova de Lisboa), Iспанія (University of Navarra and University Carlos III of Madrid), Швеція (Chalmers University of Technology), Швейцарії (University of St. Gallen) ma Великобританія (University of Cambridge and University of Oxford). У свою чергу, в інтервалі 99-90 балів знаходяться 5 університетів; між 89-80 - 7 університетів; в інтервалі 69-60 - 13; в межах 59-50 - 19; 4940 - 20; 39-30 - 13; 29-20 - 19. Авторами зазначено, що університети, яким необхідно підвищити рівень працевлаштування своїх випускників більше ніж на 74\%, в основному, знаходяться у Великобританії та Швеції. При цьому університети Австрії, Бельгії, Данії, Німеччини та Нідерландів також повинні посилити заходи по підвищенню ефективності працевлаштування своїх випускників. У статті визначено, що одним із ключових фракторів, шо впливає на рівень працевлаштування випускників $\epsilon$ бренд університету. Таким чином, на основі отриманих результатів встановлено, що рівень працевлаштування випускників університетів, що фрормують історію свого бренду $\epsilon$ вищим порівняно з іншими університетами, які не займаються питаннями промоції власного бренду.

Ключові слова: аналіз середовища функціонування, ефективність, трудова зайнятість, вища освіта, продуктивність.

Manuscript received: 01.07.2019

(C) The author(s) 2019. This article is published with open access at Sumy State University. 